\title{
Happy Mother's Day to patients I have lost
}

Tarvez Tucker, MD

Neurology ${ }^{\circledR}$ 2020;94:792-793. doi:10.1212/WNL.0000000000009388
Correspondence

Dr. Tucker

tuckerta@ohsu.edu

In our neuroscience ICU, I have found that men and women often have very different final thoughts. Women, if they are mothers, tend to speak to or about their children. Men speak about their spouses or partners or, no matter what their age, about their own mothers.

In memory of mothers I have lost:

\section{Emily}

She had been shot in the head and chest in the crossfire of a senseless drive-by shooting on a rainy night, more typical of Midwestern storms than Portland's. Her injuries were not survivable.

Before she closed her eyes, she spoke softly to the ER nurse. "Take care of Connor," she said steadily, of her 4-year-old son, waiting at home, who didn't know yet. "Thunder scares him."

\section{Kristin}

It had started with a brief twinge of pain that shot down from her lower back to her leg. A young mother of 5, she ignored it for weeks, thinking she had just pulled a muscle lifting one of her chubby toddlers. But her family physician, a kind man whose practice spanned 30 years, was worried. He ordered an MRI scan, which showed an invasive tumor, Ewing sarcoma, that had spread to the bones of her spine and pelvis. At first, the cancer responded to chemotherapy and radiation. Then, 6 months later, cooking in the kitchen, she had a seizure. Four walnut-sized tumors had metastasized to her brain. By the time I met her, she had already had 3 surgeries to resect the tumors, which kept growing back.

Her neurosurgeon strode confidently into the room, white coat so crisp it rustled. "Let's get this out again, Kristin, just another week or 2, and you'll be better... on your way home." She asked how much more time the operation would give her. He replied gently, perhaps 1 or 2 months. She looked at her kids, clambering all over the bed with her, dressed in Sunday clothes for Easter. She thanked her surgeon, and then went home to dye eggs instead.

\section{Jeanette}

The tiny bacteria multiplied quickly in her heart, settling like clinging caterpillar feet on the delicate leaflets of her mitral valve. The species was so unusual we had to look it up, and could hardly pronounce it: Staphylococcus lugdunensis. She hadn't felt sick, just tired, but she was 83, and thought that was just the reason. But then her heart began to fail. The cardiothoracic surgeon was direct: she could be cured. But not before staying in the hospital for 4 more weeks, to receive antibiotics through a slender tube inserted into her chest. After that would be open-heart surgery, stopping her heart for several hours on cardiac bypass so that he could replace the failing valve.

To her daughter, and to us, on the other side of the curtain, the decision seemed straightforward. But for Jeanette, even trying to eat pudding was exhausting. The letting go, not whatever life remained, was important for her. And so, she did. She waited until her daughter had gone 
home, tired after 4 nights at her bedside. Determined, at peace, in her daughter's words later, "she set her spirit to wings to cross over."

She left Staphylococcus lugdunensis in the bed behind her.

\section{Aya}

Their pickup truck was stopped at a red light, and struck from behind by a distracted driver going much too fast. Her twin girls strapped in booster seats in the back were killed instantly. Her husband's pelvis and ribs were fractured and Aya's head was thrown into the windshield. She instantly lost consciousness and she arrived in our ICU in a deep coma. She slowly awoke, 8 days later.

She never asked. At first, we thought it was the language barrier, but although she was Japanese, she had learned perfect English. She listened to our plans for her rehabilitation, but hardly ever spoke; just "yes" or "no" to questions about pain.

Months later, in a rehab hospital, she died. We never discovered how. She died the mother of 2 girls: all she had ever wanted to be.

And in memory of a lost mother:

\section{Joe}

Long before age 89, when he fell down the stairs at home and sustained large bilateral subdural hematomas compressing his brain, Joe had made his end-of-life wishes clear. No surgery, no ventilator, no CPR. He had firm ideas about the dignity of dying, and what life and family meant to him. Only once, early in their marriage, had he mentioned to his wife of 56 years the story about his mother. She had left him in foster care when he was 9; he never knew why and never saw her again. He had never spoken of her again to his wife, and never at all to his 3 daughters, throughout his long and happy marriage.

All 4- "my girls," as he called them - were at his side when he died. They thought they knew him with the depth of detail earned by long years of family love. He recognized them, smiled, but his last words were not to them. He said, "Mom, I have missed you."

I have 4 sons. Although I've thought about it, I have no idea what my own last words might be. They might be to my husband or to my own mom, who died with my brother there, but not me. I only know I don't know how I'll say goodbye to my boys. Or let them know that, after the first was born, every Sunday since has been Mother's Day. 


\title{
Neurology
}

\author{
Happy Mother's Day to patients I have lost \\ Tarvez Tucker \\ Neurology 2020;94;792-793 \\ DOI 10.1212/WNL.0000000000009388
}

This information is current as of May 4, 2020

$\begin{array}{ll}\begin{array}{l}\text { Updated Information \& } \\ \text { Services }\end{array} & \begin{array}{l}\text { including high resolution figures, can be found at: } \\ \text { http://n.neurology.org/content/94/18/792.full }\end{array} \\ \text { Subspecialty Collections } & \begin{array}{l}\text { This article, along with others on similar topics, appears in the } \\ \text { following collection(s): } \\ \text { Critical care } \\ \text { http://n.neurology.org/cgi/collection/critical_care }\end{array} \\ \text { Permissions \& Licensing } & \begin{array}{l}\text { Information about reproducing this article in parts (figures,tables) or in } \\ \text { its entirety can be found online at: } \\ \text { http://www.neurology.org/about/about_the_journal\#permissions }\end{array} \\ & \begin{array}{l}\text { Information about ordering reprints can be found online: } \\ \text { http://n.neurology.org/subscribers/advertise }\end{array}\end{array}$

Neurology ${ }^{\circledR}$ is the official journal of the American Academy of Neurology. Published continuously since 1951, it is now a weekly with 48 issues per year. Copyright (C 2020 American Academy of Neurology. All rights reserved. Print ISSN: 0028-3878. Online ISSN: 1526-632X.

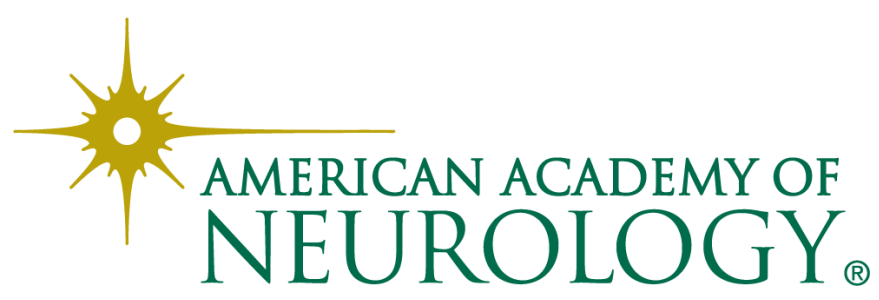

